\title{
The IsSue OF EnERgy ResourCes IN THE PODKRuŠnOHOří Region
}

\author{
Jaroslava Vráblíková ${ }^{1}$; Petr Vráblík ${ }^{2}$; Miroslava Blažková ${ }^{3}$; Eliška Wildová ${ }^{4}$ \\ Jan Evangelista Purkyně University in Ústí nad Labem, Faculty of the Environment, \\ Department of Natural Sciences, \\ Králova výšina 3132/7, 40096 Ústí nad Labem, Czech Republic \\ e-mail: ${ }^{1}$ jaroslava.vrablikova@ujep.cz; ${ }^{2}$ petr.vrablik@ujep.cz; ${ }^{3}$ miroslava.blazkova@ujep.cz; \\ ${ }^{4}$ wildova.eliska@gmail.com
}

\begin{abstract}
Coal mining has had demonstrable negative impacts on the region and the landscape. In accordance with a growing number of inhabitants, the demand for energy consumption is constantly increasing. For the future, it is important to focus primarily on renewable energy resources, which will ensure the sustainable development of the environment and society. This contribution deals with the area in the Czech Republic that has had the greatest problems in this regard, namely North Bohemia (the Chomutov, Most, Teplice, and Ústí nad Labem districts). This is an area with significant anthropogenic activity, particularly due to the intensive mining of brown coal and in relation to the power industry. The Podkrušnohoří region has recently seen the partial suspension of mining limits at the Bílina Quarry, which is the reason why the regeneration of the region through reclamation and restoration will be needed. At the same time, this contribution contains a proposal for a possible change in the power industry, i.e. regarding the sources of renewable energy in the Podkrušnohoří region that could potentially be utilized after mining in individual quarries ends after 2050 .
\end{abstract}

\section{Keywords}

Sustainable development; Renewable energy resources; Coal mining; North Bohemia.

\section{Introduction}

The Faculty of the Environment (the team from the Department of Natural Sciences) at the Jan Evangelista Purkyně University in Ústí nad Labem has been dealing with the issue of the anthropogenic burden on various regions after brown coal mining since 1992. It has collaborated on the region's regeneration with project architects, restoration company workers, mining company technicians, and farm managers. Their most important collaboration has been with Mostecká Uhelná Společnost [Most Coal Company] (now Czech Coal, a.s.), whereby research was carried out in the Slatenice, Pařidelský Lalok, Czechoslovak Army Quarry and Strrimice dumps. Another place that has been and still is the focus of attention is the Radovesická dump in the Teplice district, whose area makes it the largest external dump in the Czech Republic.

This research focused mainly on various forms of regeneration and individual types of restoration; a method called the Managed Succession of Localities after Mining in the Most Region was proposed, subsequently examined and evaluated. The issue of cultivating powerproducing plants at the dumps was also addressed. For example, in 2007-2011, the aforementioned activities received support from the Ministry for Regional Development of the Czech Republic under project WD 44-07-1, "Model Solution for the Revitalization of Industrial Regions and Zones after Coal Mining, Using the Example of the Podkrušnohoří Region". The project's objective was to prepare an analysis of the main problems in the 
Podkrušnohoři region and to study factors that disrupt the environment, such as the development of air quality, mining environment factors, disparities in the Land Fund, evaluation of recultivation in the area of interest, and other areas. The project resulted in proposals for sustainable management in the region and in the preparation and subsequent certification of the Revitalization Methodology in the Podkrušnohoří region.

At present, the theme of the revitalization of an anthropogenically affected region is being addressed within the scope of project No. QJ1520307, titled "Sustainable Forms of Management in an Anthropogenically Burdened Region". The project is being handled through the program Comprehensive Sustainable Systems in Agriculture 2012-2018, which was announced by the Ministry of Agriculture of the Czech Republic. Implementation of the project got under way in 2015, and it will be completed in 2018. This project is being carried out by the Research Institute for Brown Coal, a.s., in collaboration with the Faculty of Environment at the University of J. E. Purkyně in Ústí nad Labem. The theme of the utilization of renewable energy sources is linked to a sub-objective called "Analysis of the Podkrušnohoří Region", which is currently being addressed.

\section{$1 \quad$ Objective of the Research}

The project "Sustainable Forms of Management in an Anthropogenically Burdened Region" deals with the specific issue of one of the most anthropogenically burdened regions not only in the Czech Republic but also in Central Europe, which was part of the so-called Black Triangle formed by the regions illustrated in Fig. 1.

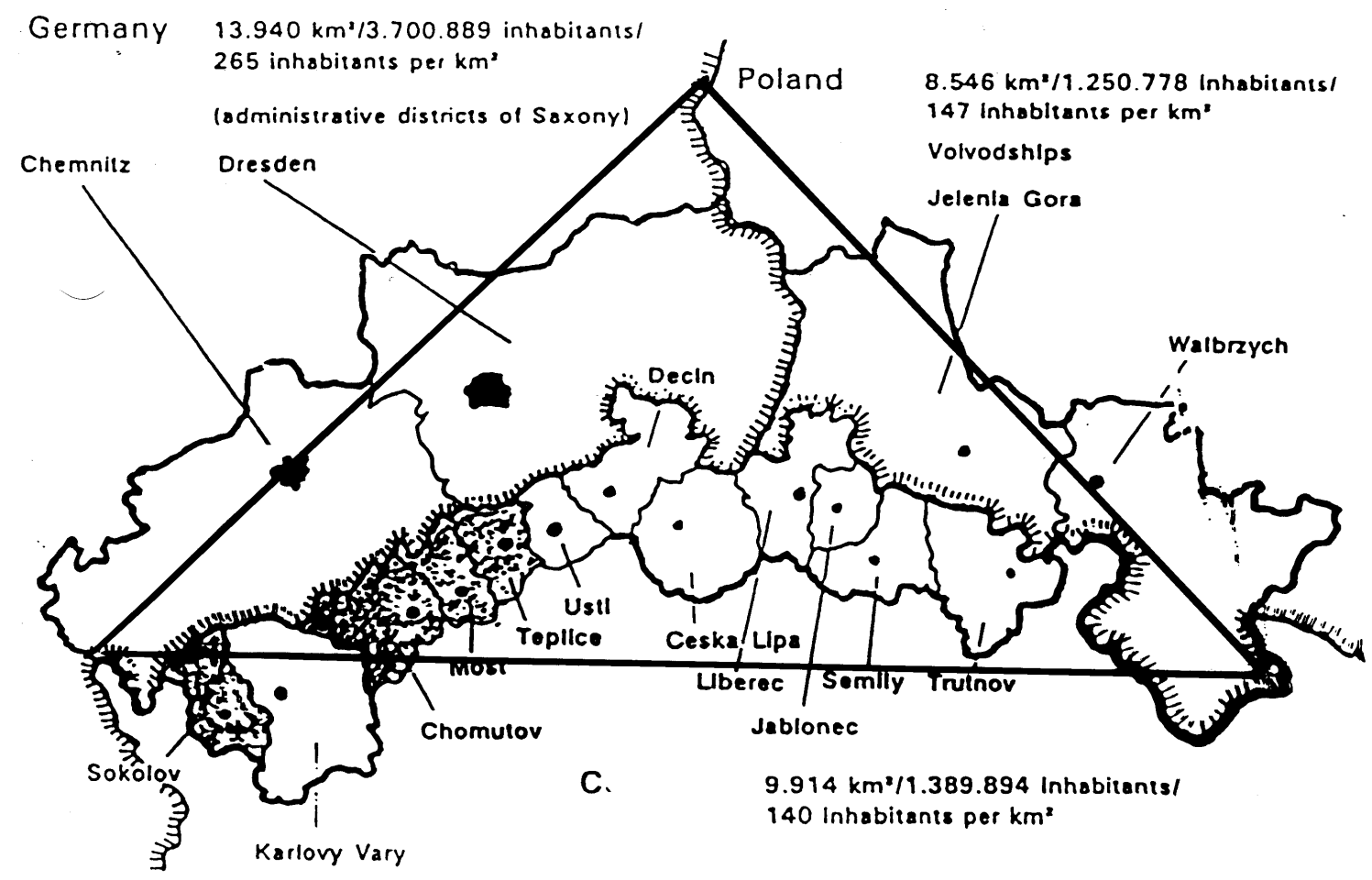

Source: [1]

Fig. 1: The designated Black Triangle area in Central Europe

The history of the name Black Triangle dates back to the 1970s. This is the area with the most polluted environment in Central Europe. On the Czech side, it was the Ústí nad Labem, 
Teplice, Most and Chomutov districts that were most affected in terms of environmental pollution. Other districts on the Czech side - Děčín, Česká Lípa, and Liberec - were polluted from emissions that came partly from Germany (the Hagenwerder power station and the Berzdorf Quarry), but mainly from Poland - The Turów Power Station and Quarry, near the town of Bogatynia.

The greatest problem in the entire Black Triangle area was air pollution from sources at thermal power stations, heating plants, open-cast coal mines, and chemical plants. The main air pollution agents were $\mathrm{SO}_{2}, \mathrm{NO}_{\mathrm{x}}$ and dust particles. In the 1980s and 1990s, the values of these agents exceeded the public health limits several times over.

The long-term burden on the environment in the previous period was the reason for its deterioration, and some of its components were also reflected in inhabitants' poor health. Project No. QJ1520307, which is currently being carried out, is contributing to management methods in the region that will create conditions for a lasting improvement in the environment and will create conditions for permanently sustainable development.

This contribution deals with the project's sub-objectives, which include the presentation of the development of mining activity in the Podkrušnohoři model area and subsequent analysis of the potential use of renewable energy sources in the area of interest.

\section{$2 \quad$ Research Methods}

The most anthropogenically burdened region in the Czech Republic is formed by the Chomutov, Most, Teplice and Ústí nad Labem districts (Fig. 2). This region has been significantly affected by intensive mining and industrial activity for almost 200 years. The area is $2,276 \mathrm{~km}^{2}$ in size and home to 486,000 inhabitants. The area is a typical industrial region, which in the late 1980 s was part of the Black Triangle area due to the open-cast mining of brown coal and its combustion in power stations. As a large number of inhabitants live in this region, an attempt is being made to integrate the area into the surrounding landscape in the form of revitalization processes, thereby ensuring the permanently sustainable development of the landscape and society. On October $19^{\text {th }} 2015$, the Government of the Czech Republic approved new territorial ecological mining limits in the Bílina Quarry via Resolution No. 827, whereby mining limits will be stipulated $500 \mathrm{~m}$ from the municipality's built-up area. In the context of this Resolution, the Government of the Czech Republic assessed:

- the economic impacts in terms of the considered variants of the suspension of coal mining limits in the territory of North Bohemia,

- social impacts on individual municipalities and on the Ústí nad Labem region,

- analysis of the need for brown coal supplies for the heating industry,

- quantification of the environmental and health impacts of the open-cast mining of brown coal in the Bílina and Czechoslovak Army quarries,

- use of extracted brown coal in combustion processes for the production of electricity and heat on the territory of the Czech Republic. [2]

With the suspension of mining limits, the anthropogenic burden on the landscape around the Bílina Quarry will also increase. After brown coal mining in the Most Basin has ended, pressure will be placed on the development of alternative energy sources there. Thus, it is essential to analyze the potential of these forms of energy in the model area in order to fulfill the energy consumption requirements of everybody who is currently dependent on its production by the combustion of brown coal. 


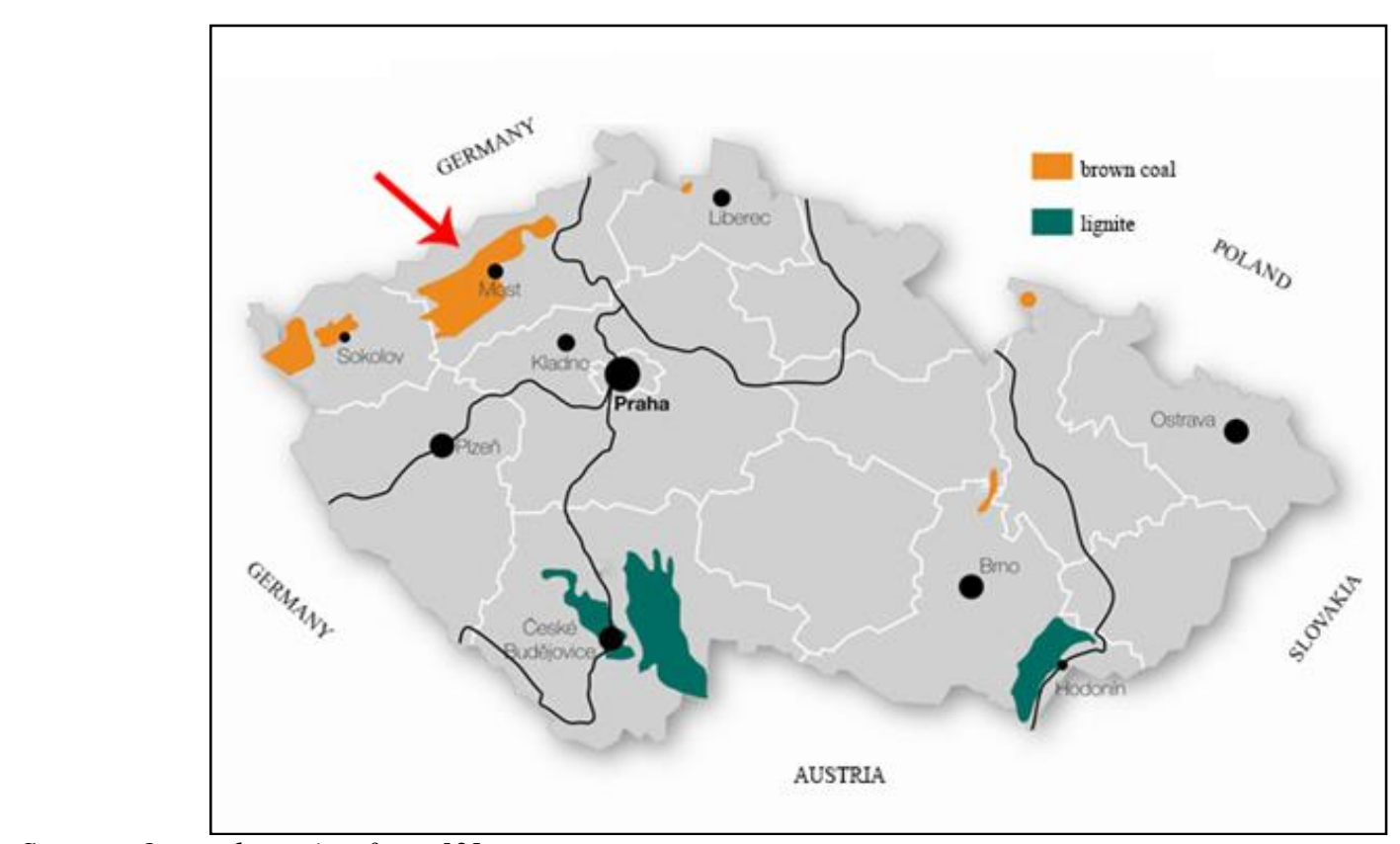

Source: Own adaptation from [3]

Fig. 2: Deposits of brown coal and lignite in the Czech Republic

\section{$3 \quad$ Coal Mining in the Area of Interest}

A particularly important source for analyzing the development of coal mining and recultivation in the North Bohemian Brown Coal District was the data from the State Mining Administration (Mining Yearbooks) from 2005-2015. In order to ensure the sustainable development of the landscape after coal mining, it is necessary to follow its revitalization methodology and abide by its individual phases and stages.

Raw material mining is the most serious anthropogenic activity in the region. It includes both underground and open-cast mining. In North Bohemia, the most obvious anthropogenic geomorphology, i.e. the result of man's direct interference with the original land surface, is in the area of open-cast brown coal quarries. Not only the physical-chemical effects, such as dust, noise and fumes have had an impact, but also the aesthetic perception has been - and continues to be - very strong. Of the total expanse of the model area $\left(2,276 \mathrm{~km}^{2}\right)$, a significant part of its southern, basinal section is directly disrupted by open-cast mining, large-scale external dumps and other related anthropogenic interference with the region and its vegetation. Since the 1960s, 116 municipalities or parts thereof have been liquidated there, including the historical part of the city of Most. At the same time, almost 90,000 people have been relocated. The concentration of production activities leads to enormous emissions and the resulting impact of air pollution on the region's landscape. [4]

The growth in electricity production, the chemical industry and metal processing in the region have been contingent on the supplies of brown coal in the model area, which have been mined industrially since around 1850 . From its beginnings until the present day, open-cast brown coal mining has affected an area of approximately $250 \mathrm{~km}^{2}$, reaching its peak with a volume of almost 70 million t/year in the 1980s (Fig. 3). 


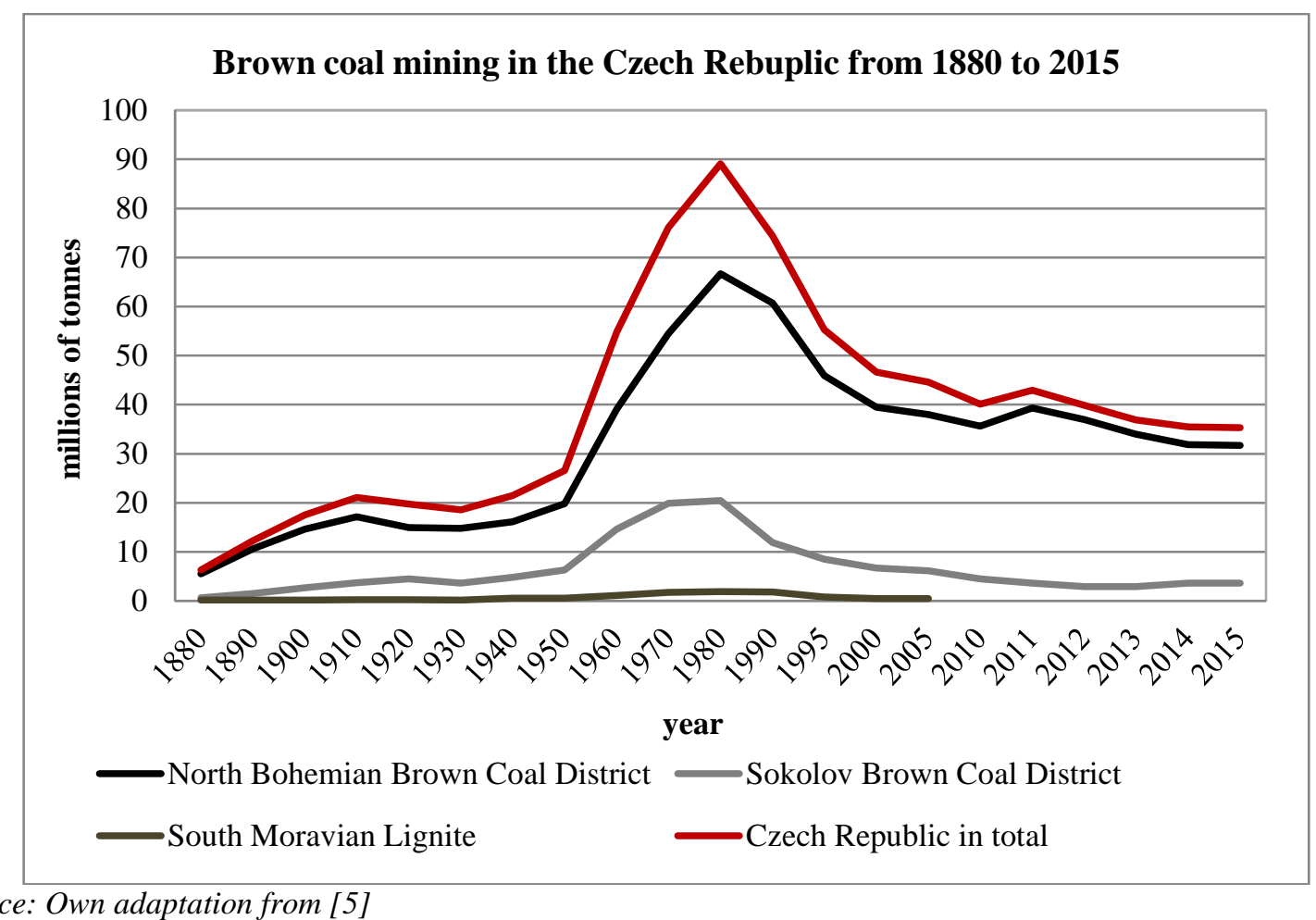

Source: Own adaptation from [5]

Fig. 3: Historical development of brown coal mining in the Czech Republic since 1880

In 2015, mining in the Most Basin reached 31.65 million tons, and the production on this territory under the Ore Mountains is carried out by the following quarries:

- Czechoslovak Army Quarry - Severní Energetická, a.s.,

- Vršany Quarry - Šverma - Vršanská Uhelná, a.s.,

- Libouš Quarry - Severočeské Doly, a.s., Nástup Tušimice Quarries,

- Bílina Quarry - Severočeské Doly, a.s., Bílina Quarries.

The last underground quarry in the basin, the Centrum (Kohinoor) Quarry, mined its last coal on April 1, 2016, and the quarry is now gradually being closed down. An overview of mining in individual quarries and the Centrum Quarry over the last 10 years is shown in Fig. 4. According to current plans, given a similar annual mining volume and in compliance with the existing limits in the Czechoslovak Army Quarry, mining in the North Bohemian Brown Coal District (SHR) should end between 2050 and 2055 [6] by mining the last of the coal supplies in the Vršany Quarry in the Slatinice extraction area and the Bílina Quarry, whose continuation beyond the originally stipulated limits was decided on by the government in October 2015. 


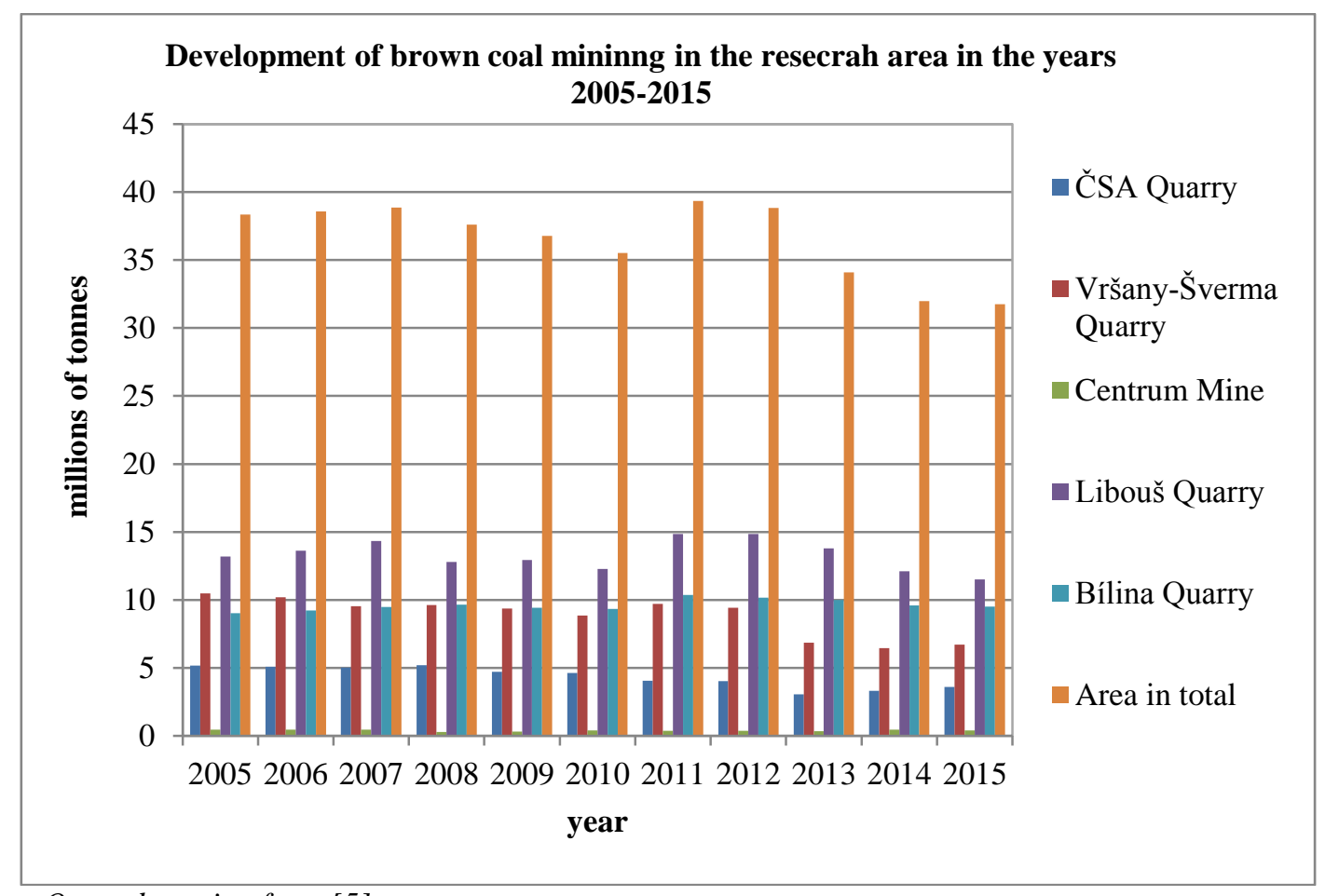

Source: Own adaptation from [5]

Fig. 4: Development of coal mining in SHR in 2005-2015

Some $89.7 \%$ (31.65 million tons) of brown coal in the Czech Republic was mined in the model area in 2015, and approximately $40 \%$ of the installed power generation capacity of the Czech Republic is concentrated there on the basis of solid fossil fuels (steam-electric power stations), for which approximately $85 \%$ of the fuel base comprises brown coal. The indicated concentration of production activities leads to enormous emissions and the resulting impact of air pollution on the region's landscape, and it plays a part in the comparatively poor evaluation of the region's environmental quality factor within the scope of the Czech Republic.

\section{$4 \quad$ Renewable Energy Resources in the Czech Republic}

To achieve the objectives of permanently sustainable development in the region, we must take gradual steps to secure the creation and development of legislation and measures in the price area, and limit the use of non-renewable sources. The main measures that will help us achieve these objectives are fuel economy and meeting consumption needs through renewable sources. From the perspective of sustainable development, it would be appropriate to fiscally differentiate between non-renewable and renewable sources; to impose tax penalties on nonrenewable sources, particularly carbonaceous fuels, and provide tax breaks for demonstrably economical technology and business. A duty should be imposed on the import of energydemanding technology, and, on the contrary, economical technology that utilizes renewable sources should be exempt from fees. At the same time, the sale of energy abroad should not be supported.

Energy has great significance for individual branches of the national economy. Any movement in the price area will affect costs in all branches, including the population's expenses. Energy prices also significantly affect the structure of industry, utilization of renewable resources, prices of products etc. [7] 
The essence of the problem lies in the fact that, if the current trend continues, all nonrenewable sources will be exhausted in a short time, which is why alternative renewable energy sources (RES) must gradually be found to take their place.

Given the level of GDP created, the Czech Republic consumes more primary energy sources (PES) and electricity than the average for EU countries. The relatively higher consumption of PES per unit of GDP in the Czech Republic is because the structure of the industry is different from the EU-15 sectoral structure, whereby domestic energy sources - black and brown coal, uranium and biomass - are utilized on a long-term basis. In 2015, a significant share of the power industry in the Czech Republic was taken up by coal and gas (approximately 60\%) as well as uranium, via nuclear energy (approximately 32\%). There has been a gross increase in the share of renewable sources in electricity production in the Czech Republic of $2 \%$ compared to the previous year (6\%) (Fig. 5).

\section{Electricity production in the Czech Republic (\%)}

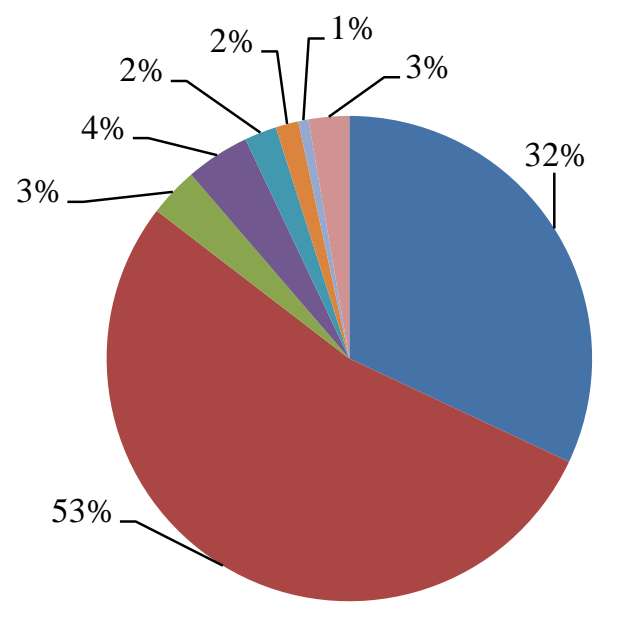

- Nuclear

- Steam-electric

- Combined-cycle

- Gas and combustion

- Hydroelectricity

$\square$ Pumped-storage

Wind

Photovoltaics

Source: Own adaptation from [8]

Fig. 5: Gross electricity production in the Czech Republic in 2015

The share of RES in domestic gross consumption (MWh) was $13.27 \%$ in 2015. In comparison with 2014, this means an increase in the share of RES in domestic gross consumption in the Czech Republic of $0.1 \%$.

Overall, landfill gas and biogas still assume the largest share of energy production from renewable sources $(28 \%)$, and this category has been constantly on the rise since 2006 . In 2015, the share of photovoltaic, 24\%, was the largest since 2006. The same development applies for biomass, which had a $22 \%$ share in the production of electricity from RES in the Czech Republic in 2015. In 2015, wind power stations were also at their greatest year-on-year maximum in the share of electricity production $(6 \%)$. On the contrary, hydroelectric power stations above $10 \mathrm{MW}$ saw their biggest decline in their share of electricity production since 2006 (8\%) (Fig. 6). [8]

At present, in terms of legal regulations, the use of biofuels in the Czech Republic is stipulated mainly by the obligation to mix them with mineral fuels. This obligation was first introduced in September 2007 for the FAME (fatty acid methyl ester) additive to diesel (2\% by volume), and since 2008 it has been applied to the addition of bio ethanol to petrol. The domestic production and import of bio ethanol in 2015 remained at almost the same level as in 2014. [9] 


\section{Electricity production from renewable energy sources in 2015 (\%)}

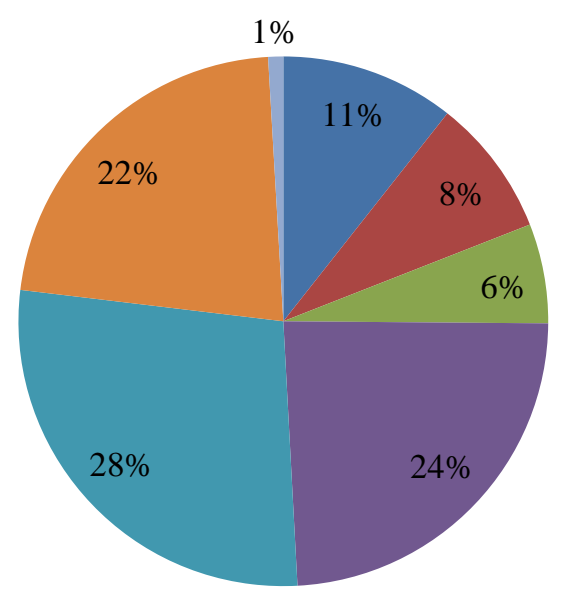

- Small hydroelectric power stations

- Hydroelectric power stations

Wind power stations

- Photovoltaics

- Biogas and landfill gas

- Biomass

- BMW

- Biodegradable Municipal Waste

Source: Own adaptation from [8]

Fig. 6: Electricity production from RES in 2015 (\%)

\section{Renewable Energy Resources in the Model Area}

The Annual Report on the Operation of the Power Industry in the Czech Republic for 2015 shows that energy production in most regions is dominated by steam-electric power stations, mainly in the Ústí nad Labem, Central Bohemian and Moravian-Silesian regions. In the Ústí nad Labem region, a significant proportion of energy production is by combined-cycle power stations, as it is in the Karlovy Vary region. In the South Bohemian region and Vysočina region, the energy production mainly comes from nuclear power stations. In terms of RES, a significant proportion of energy is produced by hydroelectric power stations in the Central Bohemian region; in Vysočina and the Olomouc region, pumped-storage power stations are relatively dominant; and photovoltaic account for a small proportion of energy production in the Central Bohemian, Ústí nad Labem, Plzeň, South Bohemian, Zlín and particularly South Moravian regions.

In order to ensure the sustainable development of the model area after the end of mining and the use of brown coal in the power industry, we have to carry out a detailed analysis of the potential of renewable sources to ensure that society's energy demands are covered. First, however, we have to analyze the existing capacity of all thermal power stations that are found in the Podkrušnohoří region. The ČEZ Group operates coal-fired power stations and heating plants in a total of 13 localities on the territory of the Czech Republic. Most of them burn North Bohemian brown coal and, for practical reasons, they are situated in the immediate vicinity of large quarries in North and Northwest Bohemia. They include the following coalfired power stations: Ledvice, Počerady I., Počerady II., Prunéřov, Tušimice I. and Tušimice II., which currently have an installed capacity in all power station blocks of 3,620 MW . [10]

For now, the anthropogenically burdened territory of North Bohemia has the highest installed capacity within the scope of RES energy from solar sources (108.21 MW), as set forth in Table 1. In this case, however, this is not an efficient or sustainable choice, as this high installed capacity came about because the construction of a solar power station was economically advantageous while a subsidy program was in place. This was caused by the abnormal and unsuitable construction of solar farms without taking into account the return on investment or the suitability of the installation. At the same time, the Agricultural Land Fund took effect (Fig. 7). 


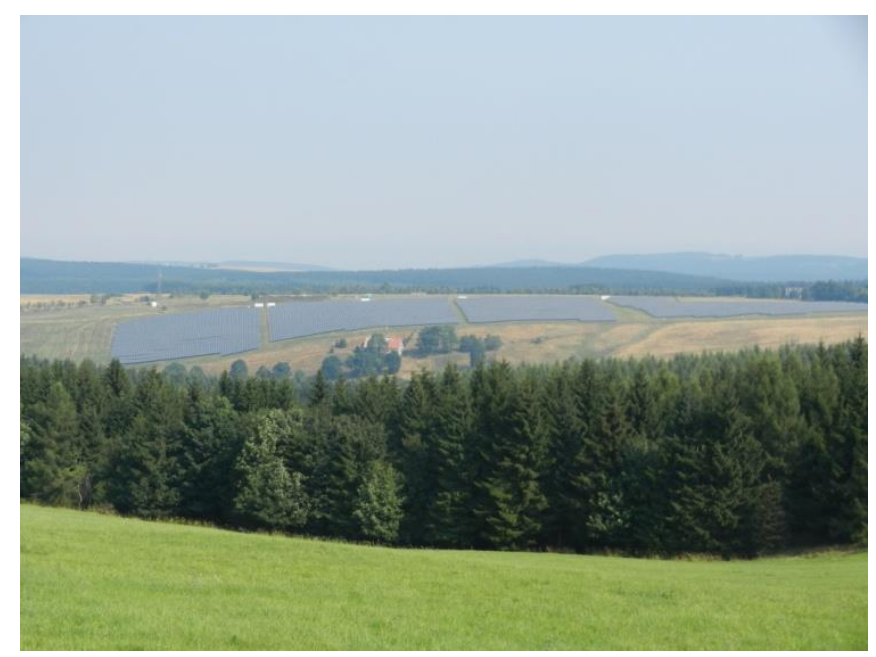

Source: Photo by Vráblik, 2015

Fig. 7: Photovoltaic power station in Moldava in the Ore Mountains (Teplice district)

Renewable energy from hydroelectric power stations is also relatively well represented in the model area; nevertheless, it does not seem to have the potential for the future, as there is currently a problem with drought and the water supply, both there and in the Czech Republic in general. The highest installed capacity is on the Elbe River (19.5 MW). Biomass processed in biogas stations has a certain future in this region if it receives more support. At present, 4.2 MW is installed in the area of interest. These stations have an advantage in that they process both animal and plant waste. Energy from wind power stations has the greatest potential for the region; this is a mountainous area, where regular air currents are typical. At present, 87 MW is installed in the Ore Mountains. However, this method has caused a great deal of controversy, as the inhabitants have criticized certain aspects such as noise, unsightliness and the danger to the fauna living in the vicinity.

Tab. 1: Overview of the installed RES capacity in the analyzed area for 2015

\begin{tabular}{|l|c|c|c|c|}
\hline \multirow{2}{*}{ District } & \multicolumn{4}{|c|}{ Installed RES capacity [MW] } \\
\cline { 2 - 5 } & Wind & Hydroelectricity & Solar & Biogas \\
\hline Chomutov & 55.80 & 16.12 & 47.30 & 0.99 \\
\hline Most & 17.00 & 7.62 & 8.68 & 0.77 \\
\hline Teplice & 10.00 & 0.00 & 40.82 & 0.68 \\
\hline Ústí nad Labem & 4.00 & 19.50 & 11.41 & 1.76 \\
\hline MA in total & 86.80 & 43.24 & 108.21 & 4.20 \\
\hline
\end{tabular}

Source: Own adaptation from [11], [8], [12], [13]

Every region should be approached individually in terms of its geographic and climatic parameters and the population's priorities and requirements. In this regard, the Czech Republic has limited options for utilizing RES because there aren't suitable conditions for most of them here. A comparison of the installed capacity of coal fired power stations in the Podkrušnohoří region $(3,620 \mathrm{MW})$ with a total installed capacity of RES in the analyzed area of 242.4 MW shows the long-term task involved in searching for other suitable localities for RES as future alternatives after the mining of brown coal comes to an end in 2050.

Geothermal energy is now becoming one of the most attractive sources of renewable energy. Approximately 6,000 MW of capacity is installed in geothermal power stations worldwide, which is only a minute fraction of the overall potential. Countries that actively utilize geothermal energy include Iceland, New Zealand, Japan, the United States and others. For example, the geothermal projects realized in Germany - Altheim and Unterhaching (Bavaria) 
and Landau (Rhineland) - can serve as positive examples of the utilization of this source in Europe. In the Czech Republic, a similar example is the town of Litoměřice (Ústí nad Labem region).

In the research assessment of the geothermal potential, the Czech Republic is not lagging behind other countries in the world. The geothermal potential in the individual parts of our region varies considerably, particularly in relation to geothermal, geological and hydrogeological conditions. When incorporating the territory of a certain region, we must divide it into areas that are most suitable for the utilization of geothermal energy for individual buildings and areas that are suitable for larger sources that can be used for the large-scale supply of heat or electrical energy production. Based on experience from other countries with similar geological structures, the Czech Republic also has potential geothermal energy sources. Heat flow anomalies have been registered in the area of the Ohárecko Rift, i.e. the Podkrušnohoří region, the western part of the Czech chalk table and the OstravskoKarvinská Basin. These are so-called low temperature hydrothermal sources, i.e. to a temperature of 100 degrees, and the geothermal energy of so-called hot dry rocks, whose potential at depths of 3,000-5,000 $\mathrm{m}$ is considerably higher. Research into, and utilization of, these sources should be supported more in the future. [14]

Various studies show that the gradual growth of renewable sources and the energy-related modernization of buildings in the Ústí nad Labem region can create as much as 2,300 jobs. Significant options for the more efficient handling of thermal energy in the Ústí nad Labem region also include the energy-related renovation of buildings. Quality reconstruction using wall insulation, window replacement and the use of modern managed ventilation technology with heat recuperation will save an amount of heat corresponding to normal consumption by almost 60,000 households and 33,000 family homes [15].

\section{Conclusion}

Due to lower fossil fuel supplies, the energy situation will be a serious problem in the third millennium, and it requires a solution. Another topical issue, particularly under the conditions existing in the Czech Republic, will also be the search for, and utilization of, other sources within the scope of RES, for example the cultivation of biomass for energy purposes on the recultivated territory of the Podkrušnohoři dumps, and the use of additional solar sources in brownfield-type areas and buildings.

The issue of the power industry and energy use must be globally linked with current opinions on options for dealing with the climate change. Carbon dioxide emissions will have to be reduced significantly in the coming decades, and adaptive measures will gradually have to be taken to prepare for possible climate change.

Permanently sustainable development is a basic prerequisite for the development of the contemporary society, and should be the top priority during planning processes. In the future, in the anthropogenically burdened region of Podkrušnohoří, we can consider the potential use of not just newly created bodies of water within the scope of hydrological recultivation (Bílina Quarry, Czechoslovak Army Quarry, Vršany Quarry), but also the utilization of the potential of renewable energy sources.

\section{Acknowledgements}

This article was supported by project QJ1520307 entitled "Sustainable Forms of Management in an Anthropogenically Burdened Region". This project was realized with financial support from state budget resources through the KUS program, Ministry of Agriculture of the Czech Republic. 


\section{Literature}

[1] BLAŽKOVÁ M.: Black Triangle - Most Polluted Part of Central Europe. Regional Approaches to Water Pollution in the Environment. NATO ASI Series, 2. Environment Vol.20. Kluwer Academic Publishers, 1996. Printed in the Netherland. pp. 227-249.

[2] Usnesení vlády ČR č. 827. 19. 10. 2015: Řešení dalšího postupu územně ekologických limitů těžby hnědého uhlí v severních Čechách. Availbale from WWW: https://apps.odok.cz/zvlady/usneseni/-/usn/2015/827

[3] VRÁBlÍKOVÁ, J.; WILdOVÁ, E.; VRÁBLÍK, P.: Sustainable Development and Restoring the Landscape after Coal Mining in the Northern Part of the Czech Republic. Journal of Environmental Protection. 2016, Vol. 7, 1483-1496. ISSN: 2152-2197. DOI: 10.4236/jep.2016.711125

[4] VRÁBLÍKOVÁ, J. et al.: Revitalizace území v Severních Čechách. Ústí nad Labem. FŽP UJEP, 2011. 294 p. ISBN 978-80-7414-396-0.

[5] Kolektiv pracovníků státní báňské správy: Hornická ročenka 2005-2015. Český báňský úřad a Zaměstnavatelský svaz důlního a naftového průmyslu, 2016. Ostrava.

[6] KAŠPAR, J.: Vliv těžby na krajinu zájmového území Mostecka a jeji obnova. Dílčí zpráva k projektu QJ1520307 - Udržitelné formy hospodaření v antropogenně zatižené krajině. 2015. 19 p.

[7] VRÁBLÍKOVÁ, J., VRÁBLÍK, P., ZOUBKOVÁ, L.: Tvorba a ochrana krajiny. Univerzita J. E. Purkyně v Ústí nad Labem, Fakulta životního prostředí, 2014. 150 p. ISBN: 978-80-7414-740-1.

[8] Energetický regulační úřad: Roční zpráva o provozu ES ČR. (Annual Report on the Operation of the Power Industry of the Czech Republic) Oddělení statistiky a sledování kvality ERÚ, 2015. Praha, 35 p.

[9] Ministerstvo zemědělství: Zpráva o stavu zemědělství ČR za rok 2015 „Zelená zpráva“. 2015. Praha, 448 p.

[10] Skupina ČEZ: Uhelné elektrárny v ČR [online]. Available from WWW: https://www.cez.cz/cs/vyroba-elektriny/uhelne-elektrarny/cr.html

[11] Česká společnost pro větrnou energii: Větrné elektrárny $v \check{C} R-$ Aktuální instalace $v$ Ústeckém kraji. [online]. Available from WWW: http://www.csve.cz/mapa-vetrnychelektraren/ustecky

[12] Elektrárny.pro: Seznam a mapa FVE v ČR s možností vyhledávání. [online]. Available from WWW: http://www.elektrarny.pro/seznam-elektraren

[13] Česká bioplynová asociace: Mapa bioplynových stanic. [online]. Available from WWW: http://www.czba.cz/mapa-bioplynovych-stanic/

[14] BLAŽKOVÁ, M.: Metodika $k$ hodnocení geotermálního potenciálu v modelovém území Podkrušnohoří. FŽP UJEP, 2010. Ústí nad Labem. 89 p.

[15] Občanské sdružení kořeny: Budoucnost Ústeckého kraje: obnovitelné zdroje a modernizace budov. [online]. Available from: http://www.koreny.cz/news/budoucnostusteckeho-kraje-obnovitelne-zdroje-a-modernizace-budov/

prof. Ing. Jaroslava Vráblíková, CSc.; doc. Ing. Petr Vráblík, Ph.D.;

doc. RNDr. Miroslava Blažková, Ph.D.; Ing. Eliška Wildová 


\section{PROBLEMATIKA ENERGETICKÝCH ZDROJU゚ V PODKRUŠNOHOŘÍ}

Těžba uhlí má prokázané negativní dopady na území a krajinu. S rostoucím počtem obyvatel jsou stále zvyšovány nároky na energetickou spotřebu. Pro budoucnost je důležité se zaměřit především na obnovitelné zdroje energie, které zajistí udržitelný vývoj životního prostředí a společnosti. Tento př́ípěvek se zabývá oblastí, která má v České republice v tomto směru největší problémy, a to jsou Severní Čechy (okresy Chomutov, Most, Teplice, Ústí nad Labem). Jde o oblast s výraznými antropogenními zásahy zejména kvůli intenzivní těžbě hnědého uhlí a v souvislosti s energetikou. V současné době došlo v oblasti Podkrušnohoří $\mathrm{k}$ částečnému prolomení limitů těžby na lomu Bílina, a proto bude do budoucna velice důležitá obnova území v rámci rekultivací a revitalizací. Zároveň příspěvek obsahuje možné směřování $\mathrm{v}$ oblasti energetiky, tedy jaké obnovitelné zdroje energie v Podkrušnohoří mají potenciální využití po ukončení těžby na jednotlivých lomech po roce 2050.

\section{PROBLEME DER ENERGIEN IM VORERZGEBIRGE}

Kohleförderung hat nachweisbar negative Auswirkungen auf die Umgebung und die Landschaft. Mit steigender Einwohnerzahl werden die Ansprüche an den Energieverbrauch ständig erhöht. Es ist wichtig, sich für die Zukunft vor allem auf erneuerbare Energien zu konzentrieren, die die nachhaltige Entwicklung der Umwelt und der Gesellschaft sichern. Dieser Beitrag beschäftigt sich mit dem Gebiet, das in der Tschechischen Republik in dieser Hinsicht die größten Probleme hat, und zwar Nordböhmen (die Landkreise Chomutov, Most, Teplice, Ústí nad Labem). Es geht um ein Gebiet mit markanten anthropogenen Eingriffen besonders wegen der intensiven Förderung von Braunkohle und im Zusammenhang mit der Energiewirtschaft. Gegenwärtig ist es im Gebiet des Vorerzgebirges zur teilweisen Durchbrechung der Förderlimits im Bruch Bílina gekommen, und deshalb werden die Erneuerung des Gebiets im Rahmen der Rekultivierung und Revitalisierung sehr wichtig sein. Gleichzeitig enthält der Beitrag eine mögliche Orientierung auf dem Gebiet der Energiewirtschaft, also welche erneuerbaren Energien im Vorerzgebirge nach Beendigung der Förderung in den einzelnen Brüchen nach 2050 eine mögliche Verwendung finden werden.

\section{ZASOBY ENERGETYCZNE NA PODGÓRZU RUDAWSKIM}

Wydobycie węgla wpływa zdecydowanie negatywnie na obszar i krajobraz. Wraz ze wzrostem liczby mieszkańców nieustannie zwiększa się zapotrzebowanie na energię. $\mathrm{Na}$ przyszłość ważne jest skoncentrowanie się przede wszystkim na odnawialnych źródłach energii, które zapewnią zrównoważony rozwój środowiska naturalnego i społeczeństwa. Niniejszy artykuł dotyczy obszaru, który pod tym względem boryka się z największymi w skali kraju problemami, tj. Północnych Czech (powiatów Chomutov, Most, Teplice, Ústí nad Labem). Jest to region o znacznych zmianach antropogenicznych, związanych przede wszystkim $\mathrm{z}$ intensywnym wydobyciem węgla brunatnego oraz $\mathrm{z}$ energetyką. Aktualnie w regionie Podgórza Rudawskiego przekroczono częściowo limity wydobycia w kopalni odkrywkowej Bílina, w związku z czym w przyszłości bardzo ważne będzie zrewitalizowanie i zrekultywowanie tych terenów. Artykuł przedstawia także możliwe kierunki w dziedzinie rozwoju energetyki pokazując, $\mathrm{z}$ jakich odnawialnych źródeł energii będzie można potencjalnie korzystać na Podgórzu Rudawskim po zakończeniu wydobycia w poszczególnych kopalniach po 2050 roku. 